\title{
The Use of Language in the Making of Romanian Nationalism from Dimitrie Cantemir and Mihai Eminescu to the Iron Guard and National Communism
}

\author{
Lucian TION \\ PhD, Visiting Professor/IDUB Researcher \\ Department of Audiovisual Media and Film \\ University of Łódź \\ MA, University of Amsterdam \\ PhD, National University of Singapore \\ E-mail: lucian.tion@filologia.uni.lodz.pl
}

\begin{abstract}
This article explores the role that language played in the development of national identity in Romanian cultural discourses from the writings of Dimitrie Cantemir in the $18^{\text {th }}$ century to those of Mihai Eminescu in the second part of the $19^{\text {th }}$ century. The article also makes use of the theories of Daco-Roman continuity and the theory of Latin descent. Seen in relation to the Latinization of Romanian that occurred in the $18^{\text {th }}$ and the $19^{\text {th }}$ centuries, these concepts are considered as contributing to the emergence of the so-called Romanian exceptionality. Cantemir's and Eminescu's writings are analysed in relation to the rise of fascism in interwar Romania as well as to the transformation of internationalist communism into nationalism after the purges of the 1950s and the re-orientation of the Romanian socialist regime towards the Right. The use of language for political purposes is ultimately considered as one of the elements that contributed to the hold that fascism and nationalism had on the Romanian psyche, so much so that nationalism survived (and was indeed boosted) throughout the socialist period and into post-socialism. The article concludes that this has contributed to the ongoing identity crisis of the national self-image and will continue to do so in the $21^{\text {st }}$ century.
\end{abstract}

Keywords: nationalism, fascism, Romania, Eminescu, Cantemir, Codreanu, communism, Iron Guard, Ceauşescu 


\section{Introduction - What Is a 'Nation'?}

As Friedrich Nietzsche observed vis-à-vis our relationship with the past in his essay Uses and Abuses of History for Life, 'We are the outcome of earlier generations, we are also the outcome of their aberrations, passions and errors, and indeed of their crimes; it is not possible wholly to free oneself from this chain.' To remedy this wrong, the philosopher suggests that 'we give [ourselves], as it were aposteriori, a past in which one would like to originate in opposition to that in which one did originate' (Nietzsche 1997: 76). Despite Nietzsche's positive intent, this effort also means that modernity would prefer to construct its own version of history, or histories, rather than accept the past qua past and that there are as many different histories as we have time to spin them in the form of self-spun tales.

The concept of self-spun tales belongs to historian Paul Cohen, who believes that 'narrativizing', or, as he puts it, 'spinning tales' out of the events we experienced at one point in our lives is the primary method through which we make sense of the past. Just as the Chinese who rebelled against foreign spheres of influence in 1901 were unaware of their participation in an event later called the Boxer Rebellion or as soldiers in 1914 did not know that they were fighting in World War I (Cohen 1998: 8) history is only written - as Nietzsche would put it - a posteriori. That does not only mean that history is written after the events which it narrates but that the narration of the events themselves is influenced by the point of view of the person narrating them. Extrapolating, Cohen argues that in our attempt to 'make sense' of what has happened to and before us, we reconstitute and resituate events from the exclusive perspective of the present moment.

If we are to believe Nietzsche and Cohen, it would not be far-fetched to argue that modernity, through the notion of progress it puts forward, represents the negation of its own existence in that in order to achieve the progress it seeks, modernity has to continually destroy the little progress it has made. What this view of history also implies is that in order to uphold modernity's premises, we necessarily lose sight of real history. Singled out as a contradiction by both Koselleck and Adorno, this leads one to see modernity as intrinsically and immediately dependent on its own continuous violent destruction, as evident in the amount of energy necessary to sustain it.

To better understand the effects of modernization on history, it is worth looking briefly at the main theories of modernization, which tried to make sense of the past by investigating the processes responsible for the emergence of nationalism. For all their complex and long-winded history, the theories of nationalism fall roughly into two camps. What I call 'the modernists' camp', represented by Ernest Gellner, postulated that nationalism sprung from the heavy industrialization period that occurred in Europe in the $19^{\text {th }}$ century, therefore as a direct consequence of modernization. While Benedict Anderson famously posited that nations are the product of 'imaginary communities' connected to the emergence of national 
literary languages, which were themselves aided by 'print capitalism' (Anderson 1983: 45), Gellner posits that 'nationalism is the direct, or indirect, consequence of industrialization with its new division of labour' (Conversi 2012: 14).

Subscribing to this view, the other scholar of nationalism, Eric Hobsbawm, goes as far as to affirm that nations, as we know them today, came into being as a consequence of 'invented traditions' and that before 1884 the word 'nation' simply meant 'the aggregate of the inhabitants of a province, a country or a kingdom' (Hobsbawm 1990: 14). Although they claim to be 'rooted in the remotest antiquity', nations 'must include a constructed or 'invented' component' (Hobsbawm 1983: 14). Supporting Hobsbawm's view, Hugh Trevor-Roper exemplifies the invention of the modern nation with the humorous case of the Scottish kilt and bagpipe tradition: Before the union with England, Trevor-Roper writes, both these markers were seen as a sign of barbarism, vestiges from a poverty-ridden past. In protest to the union, they acquired in modern times a distinct 'national' character, becoming an omnipresent symbol of uniqueness through their display in various ceremonial acts, whence they became the bearers of 'Scottish tradition' (Trevor-Roper 1983: 15).

Anthony D. Smith and Liah Greenfeld belong to a different camp, which, with some overemphasis perhaps, I call the 'essentialist' one. Unlike the modernists analysed above, Smith postulates that nations in the modern sense of the word have existed since at least the Middle Ages and that they represent the embodiment of a pre-modern ethnie, which Smith identifies with 'old elite high cultures' (Smith 1998: 42) that would later evolve and endure as nations (Smith 1998: 127-131). Greenfeld also coherently argues that the concept of the nation - a resurgence of the ancient natio of Latin origin - can first be recorded during the English civil war (1642-1651) and that the concept acquired enough tenure to be later adopted by the French, Russians, and Germans as a model of sorts, towards which the aristocracy of those nations aspired (Greenfeld 1992: 47). If the French and the Russians emulated early British nation-making practices, this was done in a very conscious manner, Greenfeld argues, as England represented a 'model' after which 'enlightened despots' (such as Peter the Great and Catherine the Great in Russia) moulded their own countries. Greenfeld makes the case that these leaders were 'people of ambition and energy far exceeding the average' (Greenfeld 1992: 191) and that they copied England's process of nation-building through the 'elevation of the populace to the position of an (at first specifically political) elite' (Greenfeld 1992: 6). However essentialistic some of her claims, Greenfeld is right to state that, after the Middle Ages, the concept of the 'nation' became associated with honour and political power - which the old Latin term lacked -, and this in turn represented the birth of the modern nation as we know it.

In this paper, I consider in what way the aforementioned theories can or cannot apply to Romanian nation-building practices, arguing that both Greenfeld's and Smith's theories regarding the transformation of the original natio into the modern nation 
in the Middle Ages and Gellner's modernization via the industrialization thesis are relevant for the Romanian context, with slight differences. First, I will be arguing that while for Greenfeld and Smith ethnie acquired value in and of itself, in Romania, the concept of ethnicity was strongly correlated with language practices and linguistics, including the use of linguistics for political purposes. Indeed, I will support this view in the last part of the essay by invoking Katherine Verdery's view of the particular type of nationalism that, she argues, took hold in Romania in the $20^{\text {th }}$ century.

Secondly, when applying Gellner's theories to $20^{\text {th }}$-century Romania, I will be arguing that not so much industrialization but the import of nationalist theories as well as the changing dynamics of modernity caused the emergence of ethnic consciousness. This later conduced to a romanticized version of nationhood, which in turn was refashioned into both fascist and (surprisingly) national-communist versions of nationalism. Put simply, I posit that the process that occurred since Cantemir's identification of Romanian as a Latin language led to the re-Latinization and continuity theory, both promoted by the representatives of Şcoala Ardeleană, or the so-called Transylvanian School for political purposes. These were later instrumentalized through the successive interventions of romanticism, fascism, and national communism into present-day Romanian nationalism.

\section{Dimitrie Cantemir and the Theory of Latin Descent}

Ascribing an overpowering role to Latin descent in the making of Romanian nationhood, the Romanian modernization process starts - not unlike Trevor-Roper's description (1983) of Scottish 'nationalization' of the kilt and bagpipe - with the thesis that Romanians are the direct descendants of the Dacians and the Romans. The Daco-Roman continuity theory prefigured by Cantemir stipulated that the ancient Dacian tribes intermarried with the conquering Romans in the territory of presentday Romania and thus birthed the Romanian language and ethnicity. ${ }^{1}$ Popularized by the representatives of the Transylvanian School in late $18^{\text {th }}$ century, this theory, which also represents the first attempt at building what Anderson (1983) later called 'an imagined community', has its origins in the writings of Dimitrie Cantemir. By tracing the evolution of this theory from Cantemir ${ }^{2}$ into the contemporary period, I investigate the degree of politicization this theory acquired vis-à-vis the process of modernization and nation building with which it is inextricably linked.

Born in a princely family in Moldova but raised at the Sultan's court, Dimitrie Cantemir (1673-1723) was undoubtedly one of the earliest humanists and foremost

1 The thesis held despite the brief duration of Roman presence in Dacia, namely between Trajan's Wars in 101-106 and the Roman retreat under Aurelian in 271-275.

2 Although Cantemir based some of his theories on earlier chroniclers who had made similar claims, an in-depth historiographic approach of the continuity theory falls outside the bounds of this article. 
representatives of enlightenment in Eastern Europe. A philosopher, geographer, linguist, musicologist, and composer, this veritable Renaissance man was also the first Romanian-born scholar who attempted to establish a historiography of the Romanian principalities at a time when imperial domination and internal regicide made these mysterious territories some of the least known in Europe.

Mainly for this reason, in a work that Cantemir envisioned as the ultimate authority on the origin of the Romanians and which was commissioned by the Berlin Academy in 1711, he resolved to dispel some of the mystery surrounding the Romanians' nebulous past and stoically convince his readers of the Latin origin of the Romanian nation (which he variably also called Moldavian or Vlach). What is of chief notice in this massive oeuvre loosely translatable as The Chronicle of the Durability of the Roman-Moldovian-Wallachians is that Cantemir, despite his declared purpose of 'fighting for [his] fiefdom' (Cantemir 1717: 5), is uninterested in making ethnic statements. Somewhat disproving Smith's and Greenfeld's theses, Cantemir seems keen on basing the theory of Latin descent on language alone, being convinced that should Romanians enjoy any sort of glory, their ethnicity would have nothing to do with it.

Differing from the English elite that Smith and Greenfeld saw as the core of later British identity, Cantemir does not hold any visions of grandeur vis-à-vis the future Romanian nation when he states that: 'no one should think we would fancy that the Roman-Moldo-Vlach people have no foreign blood mixed in their own' (Cantemir 1717: 19). ${ }^{3}$ Even when writing eulogistically about Latin origins, Cantemir has no qualms about accepting the mixture of ethnicities as a natural phenomenon. He matter-of-factly declares that of the many individuals that make up the Moldavian people none is a purebred Moldavian (Rusticus pure Moldavus nullus est in orig.), but 'those [peasants] that are they are of either Russian or Transylvanian [i.e. Hungarian] origin' (Cantemir 1933: 123). Moreover, he is de facto proud to affirm that it is almost unbelievable that such a small country could be home to so many ethnicities (Cantemir 1933: 121). In other words, proving Gellner and Hobsbawm right, language and ethnicity (let alone race) were completely distinct concepts in Cantemir's time (if even acknowledged as such), and the fact that the inhabitants of Moldova were of mixed heritage did not detract from the Moldavian pride of using a language that is assuredly (in Cantemir's view) descended from Latin.

Despite his goal of writing unbiased history, it becomes obvious relatively early in the text that what is at stake for Cantemir is not only memory, glory, or language alone (all of which Cantemir holds dear) but also the Moldavian throne, which the prince had lost three years prior when being forced to flee from the conquering Turks (Lemny 2009: 131). Under these unpropitious circumstances and faced with the probability of being unable to return to this privileged position, Cantemir feels compelled to offer as an argument for Moldavia's independence the theory of Latin

3 In this paper, all quotations from Cantemir were translated by the author. 
descent, as if (and here Greenfeld's reading of nationhood applies perfectly) the privileged status of Latin at the time could save Moldavian identity from being swallowed by one of the threatening neighbouring empires (be it Ottoman Turkish or Tsarist Russian).

Self-consciously agreeing that, according to an old proverb, 'the mouth that praises itself stinks', (Cantemir 1717: 100) he is sensible to stick to his linguistic guns, afraid to either fall into the trap of self-delusion or wake too much criticism from either the Porte or the Tsardom. Walking a fine line between politics and historiography, he argues that the Moldavian language is of direct Latin descent, notwithstanding the presence of substantial loanwords from Greek, which the author acknowledges in his previous treaty, Descriptio Moldaviae. Although he is conscious that the 'love of country might darken [his] sight' (Cantemir 1933: 154), he postulates that Moldavian is not derived from some later Italian dialect, as preceding chroniclers had held. He attempts to prove this by quoting the existence of words in Moldavian for which Italian later found 'barbaric' equivalents and lists the Latin/Moldavian/ Italian triptychs incipio/început/commincio (where commincio is the barbaric term) and albus/alb/bianco as evidence for the close adherence of Moldavian to Latin.

As ground-breaking as his linguistic arguments were in the early $18^{\text {th }}$-century East of Europe, some fissures are also present in his argumentation. Quoting a dubious statement by Cravtius, according to which it is assumed that Dacians became Roman slaves and that Roman colonists married Dacian women (Cantemir 1933: 154), he claims that words whose etymology cannot be easily inferred as descending from known languages, must be Dacian. This appears surprising coming from a polyglot like Cantemir, who not only knew Turkish and Greek but ended up living under the Tsar's protection in Russia and becoming an equal master of Slavic tongues.

Sacrificing scientific accuracy to the very love of country he feared, Cantemir makes a list of potential Dacian words, which includes the terms stejar 'oak' and heleşteu 'fishing pond'. Knowing today that the word for 'oak' in neighbouring Bulgarian is stezer, while in Czech stožar means 'pole' or 'mast', and in Slovenian stežeru means 'stick', it becomes obvious that Cantemir is going out on a limb in making not necessarily demonstrable assumptions. Similarly, there is no dissent among modern linguists today that heleşte comes from the very similar halastó, which means fishing pond in Hungarian from the root hal 'fish' and tó 'lake'.

\section{Political Linguistics}

Cantemir's naïve mistakes of the enlightenment era would influence the subsequent history of linguistics and also contribute to the creation of domestic nationalistic discourses: After almost 300 years of linguistic haggling, the etymology of the term stejar - to the surprise of professional linguists - remains a mystery in Romanian 
linguistics. If in both Cioranescu's Diccionario Etimologico Rumano from 1966 and in Breban's 1987 Dicționar general al limbii române the word stejar figures correctly with its Bulgarian etymology, in the 2010 edition of the Dicționarul Limbii Române published by the Romanian Academy, the word stejar appears as having an 'unknown origin', probably as a recognition of Cantemir's initial wayward statement in the context of the re-emergence of nationalism in post-socialism.

The different etymological explanations of a word like stejar in the various stages of Romanian nation building demonstrates the predominantly political role that linguistics has held in Romanian discourses ever since its birth in the throes of Romanian political emancipation from the Austro-Hungarian monarchy.

Pushing Cantemir's Latin-descent argument to the extremes, Petru Maior of the Transylvanian School, or Şcoala Ardeleană - as this linguistic-nationalist movement of the $19^{\text {th }}$ century was known -, initiates a discourse of lasting influence when in 1814 he asserts that Romanian and Italian were purportedly very similar to one another at the time of the Dacian conquest. However, the Romanian philologist argues that, because Italian was later modified by the lasting influences of poets like Dante, Petrarca, and Boccaccio, Romanian preserved a purity once lost in Italian. Adding more fuel to the fire of Cantemir's Latinity, Maior follows this line of argument to sing praises to a language which deserves to be reunited with its former self (which it undeservedly lost) and is among the first to call for a purification of Romanian of its Slavic elements, which, in his opinion, can be easily disposed of (Close 1974: 19).

Despite the fact that Cantemir took pride in the mixed character of Romanian, and he acknowledged influences such as those brought about by Turkish and Greek dominance of Wallachia and Moldavia, the eclectic character of the language became, in line with Greenfeld's nobility thesis, a reason for dishonour in Petru Maior's time. Indeed, $19^{\text {th }}$-century intellectuals, for reasons that need to be further researched, disapproved so strongly of Slavic languages that they considered their influence in Romanian beyond barbaric: '[...] The spectre of Slavic languages rises its ugly head above the Romanian language like an iron-clad, dark sky, such is the filthiness of the Slavic character, ${ }^{4}$ wrote Timotei Cipariu, a $19^{\text {th }}$-century cleric and academic, who was founding member of the Romanian Academy. Linguist Radu Mârza rightfully mentions that 'the concern of Latinists to marginalize foreign influences on the language and the Romanian people is well known. So is the emphasis on the external, reversible character of these influences' (Mârza 2003: 347). ${ }^{5}$

Counting on the supposed reversibility of Slavic influences, Petru Maior advocated the reform of the language in a politically motivated attempt to bestow upon Romanianness the nobility of Latinity. Proving Greenfeld's theory of noble descent correct, Maior essentialized the original ethnie that Smith claims is the core of the modern nation, but he did so with a twist. While Greenfeld and Smith

4 Cipariu qtd. by Mârza (2003: 347) - author's translation.

5 Quotation translated by the author. 
referred to the English aristocracy as possessing the mediaeval power to later shape the ethnie into a nation, Maior chose a people and a culture as remote from enlightenment-era Romanians as it was physically and chronologically possible: the ancient Romans. Motivated by this noble lineage, in a ceaseless race meant to expunge all local influences from the language, despite a past shaped by Slavonic, Turkish, Hungarian, and Greek influences, Maior and the Transylvanian School's scholars turned to French and - because of the enduring legacy of Latin continuity - to Italian for sources to 'enrich' (but de facto to purify) the Romanian language, and they called on other intellectuals to do the same.

Heeding his call, Ion Heliade Rădulescu worked hard in order to single-mindedly and authoritatively turn Romanian into a 'literary language'. In tone with Maior's advice, Heliade's work amounted to not only a purging of much of the Slavic heritage from Romanian but to a practical replacement of Slavic words with loanwords from Italian (which he considered Romanian to be no less than a dialect of). He further encouraged this practice by calling it less 'borrowing' than 'taking boldly from our mother's heritage, and from our sisters, that which is rightfully ours' (Heliade qtd. in Close 1974: 76). Despite great purification efforts, Heliade was forced to reluctantly admit at the end of his career in a letter dated to 1839 that the language naturalized too many 'foreign sayings' for Romanians to go back and completely 'cleanse it', and he considered this fact 'a fatality'. These 'foreign sayings' were the surrounding influence of Slavic and Finno-Ugric languages.

Despite sustained efforts in the subsequent decades and the transformation of a language that begins to sound increasingly Latin-based, the historiographical discourse of the first half of the $19^{\text {th }}$ century does not see much change in respect to Cantemir's concept of ethnicity. Thus, early $19^{\text {th }}$-century Romanians still see themselves as a naturally mixed people whose heritage is progressively more Latin, in a context in which blood lineage mattered less than the language one spoke, or rather, the language one was proud to speak.

Language, however, in agreement with Greenfeld's theories, did gain importance after 1830 in the political discourse as a vehicle meant to represent a 'sophisticated culture', which was literally being created under the pens of the likes of Heliade. Doubters of Maior's Latin-descent theory, such as Jernej Kopitar and Franz Miklosich, Slovenian linguists who maintained that Romanian had a closer affiliation with Slavic languages than previously thought, were being silenced, as national sentiment was gaining ground by endowing the language with 'superior qualities' and 'genius' in line with its exceptionality, under which the most 'essential traits of the national spirit' lay in waiting (Hitchins 1996: 193).

Maior's and Heliade's efforts were of a political nature. When discussing the 'utopian regressive' tendencies of the epoch, historian Sorin Antohi names not only Heliade but also Nicolae Bălcescu, Bogdan Petriceicu Hasdeu, Alecu Russo, and Gh. Asachi among 'the intellectuals of a modern nation, which had just been 
"discovered" by the West [who] were reaching into the past to legitimate their messianism' (Antohi 1999: 128). In agreement with both Nietzsche and Greenfeld, these romantics were fashioning a new past for a nation that, as Lemny put it vis-à-vis Cantemir (but applicable a century later), was still 'very little known in Europe' (Lemny 2009: 133). Moreover, this situation was not isolated to the Romanian context. Surrounding cultures in the late $18^{\text {th }}$ and early $19^{\text {th }}$ century were equally striving to create a national language and a national identity. Not unlike Vuk Karadžić in Serbia, the Romanian intellectuals at the time were beginning to use linguistic arguments politically in order to raise the status of the Romanian minority in Transylvania, or, as in Heliade's case, to gain prestige for a Wallachian culture heretofore smothered under the presence of Greek and Turkish political and commercial domination. Although their efforts can hardly be seen as contributing to the creation of Romanian nationalism, they did contribute towards the proverbial awakening of national conscience at a time when such a conscience, as elsewhere in the Balkans and Central Europe, did not truly exist. Indeed, it is only during the late $19^{\text {th }}$ century that nationalism would start to come into being, and even then in a slightly different way than it did in Western Europe.

\section{From Ethnic Consciousness to Nationalism}

It is important to point out that nationalism in Central Eastern Europe was culturally imported from the West. The revolutionary year of 1848, known mostly in Eastern Europe as the Springtime of Nations, had a very different function in Western Europe. Indeed, in Italy and France, where the movement first started, the purpose of the revolution was to replace monarchic institutions with liberal and democratic ones. As John Breuilly writes, 'nationalism had little popular appeal. What nationalism there was of political significance was rather different from the romantic, linguistic and ethnic ideas which intellectual historians have emphasized' (Breuilly 1993: 96).

In Italy and Germany, the movement also sought to unite fragmented provinces, which were a rather disbanded conglomerate of regions incorporated under several empires, in which common political and ethnic consciousness was mainly lacking. Breuilly is right when he states that Italian and German nationalisms were nonexistent before unification and that it was only the success of unification which retroactively saw the revolution as nationalistic (Breuilly 1993: 96). While it is true that revolutionaries in Western Europe fought for the Voltairian ideas of freedom of religion and democracy, the concept of self-determination that ultimately led to nationalism took longer to develop.

In its romantic form, nationalism came into existence at the time of the German enlightenment. Johann Gottfried Herder in the $18^{\text {th }}$ century was one of the first 
philosophers to define culture as an expression of Volksgeist. A term alternatively translated as either 'spirit of the people' or 'national character', Volksgeist made itself manifest for Herder through the vernacular language spoken by a particular ethnic community and thus carried the essentializing mission of modelling the national spirit through the expression of national language. Inspired by ancient Greek poetry, which he saw as expressing the spirit of the age and its people, Herder advocated for a change of language that would accommodate his essentialist view of culture, positing that 'each national language forms itself in accordance with the ethics and manner of thought of its people' (Herder 2002: 50).

It becomes clearer in this context that Maior's mission is largely indebted to Herder's ideas and that the theories of Greenfeld and Smith are only partially applicable to the Eastern European context. Instead, repositioning slightly Gellner's argument that industrialization caused nationalism to emerge as a defensive reaction against modernization, it might be fruitful to regard the arrival of nationalist theories in $19^{\text {th }}$-century Transylvania as a result of awareness of class status in relations of agricultural and industrial production. This rather Marxian view is supported by the vehemence of the anti-imperial ethos of the linguistic movement initiated by the Transylvanian School. This movement ultimately had the effect of upsetting the ethnical mix considered the norm until the $19^{\text {th }}$ century and led to the emergence of ethnic consciousness, a concept that would have real political consequences for the region.

By the middle of the $19^{\text {th }}$ century, in the wake of the 1848 revolution, ethnic consciousness and proto-nationalism would become indelibly connected with the rise of romantic nationalism in Eastern Europe and with the organicist views propagated by German enlightenment-era philosophy. If Herder set the basis of Volksgeist, Hegel developed the concept in his Phenomenology of the Spirit in a way that would have lasting influence over the next two centuries, particularly on the Romantic Movement. For Hegel, individual peoples were carriers of a certain spirit, which manifested itself in the essence of the nation (Hegel 1998: 439-440), a spirit which identified the nation as unique in relation to other peoples. This philosophy would have a powerful effect on Eastern European students in Berlin who, coming from countries under Russian or Habsburg occupation, would find them liberatory and would use them to infuse the 1848 revolutions in Central Eastern Europe with a particularly nationalistic character. For such revolutionaries, the national-linguistic connection was paramount, as it helped not only distinguish their nations from the surrounding ones but also position their nations as victims of the imperial regimes that ruled over them using a language which they perceived as alien to their own Volksgeist.

Historian Adrian Webb believes that in Western Europe the state came into existence before the principle of nationalism, while, by contrast, in Eastern Europe, since the theory was imported from the West, "the sense of cultural identity had come first, and 
it demanded a nation state for its expression' (Webb 2008: 14). This is supported by the late formation of the nation-state in East Central Europe, which, more often than not, as in the Polish, Yugoslav, ${ }^{6}$ Czechoslovak, and Romanian cases, came into being as a result of the dismemberment of multinational empires at the end of WWI. As Gellner puts it, 'nations can be defined only in terms of the age of nationalism, rather than, as you might expect, the other way round' (Gellner 1983: 55).

The movement from ethnic consciousness to the birth of the nation-state is a process that took place in the late $19^{\text {th }}$ and the early $20^{\text {th }}$ centuries in Central Eastern Europe, and it was dominated by the imported theory of ethno-linguistic nationalism that first saw its development under Herder and Hegel. When it came to the political applications of this theory, unlike in France, Italy, or Germany, which sought no implementation of nationalism in the late $19^{\text {th }}$ century until the emergence of fascism in the 1920s, in Eastern Europe the primacy of language and its strong connection with ethnicity would enjoy increasing popular appeal in the age of romantic nationalism.

\section{Eminescu's Use of Language}

Mihai Eminescu, the Romanian national poet, perfectly exemplifies what Webb called the need of incipient national culture to find a national state for its expression. Born immediately after the failed Romanian revolution of 1848 to a Ruthenian father and a Romanian mother in Bukovina, which was at the time part of the Austro-Hungarian Empire, Eminescu went to Berlin to study philosophy in the 1870s. Influenced by Herder and Hegel, upon his return to his native land, he developed theories of national identity which had been brewing in the cauldron of linguists, politicians, and theorists before him but only found in Eminescu's romantic-nationalist poetry a unified voice that represented their interests.

In a period of political upheaval, when anti-monarchic sentiment was developing in the Polish, Czech, Slovak, and Ruthenian territories, the Romanians in Bukovina, an ethnically mixed province of Ukrainian, Jewish, and Romanian ethnicities, were demanding greater political rights, including the right to use their own language in official institutions. Here, as in all territories of the Austro-Hungarian Empire that contained mixed ethnic populations, Western nationalism percolated to the level of the political discourse in the form of anti-imperial sentiment. Revolutions and demonstrations in Poland in 1830 and 1863 against Habsburg and Tsarist occupation, as well as the Czech National Revival movement of the $19^{\text {th }}$ century, in which the Czech language was institutionalized for the first time, contributed to the spread of romantic nationalism. But while the implementation of modernity in

6 The new country was called in 1918 the Kingdom of Serbs, Croats, and Slovenes. Its name would be changed to Yugoslavia only in 1929, but its political structure would remain the same. 
France and Italy took a bottom-up approach, in the East the institutions, languages, and the national state itself were imposed via a top-down effort.

This action became a double-edged sword in Romanian modernization policies. While eager to modernize along Western lines and to achieve statehood, Romania in the late $19^{\text {th }}$ century also had to face the havoc brought about by modernization. This meant a change in agricultural and social relations, the beginning of urbanization, and the slow disappearance of the romantic notion of the Romanian peasant, who was forced to enter increasingly tenuous production relations with an increasingly demanding aristocracy. While in the West the battle of modernization hinged primarily on the industrial revolution and focused on changing social relations between the old aristocracy and the emerging proletariat, in Eastern Europe, modernization acquired a primarily ethnic and linguistic character, as these attributes were the only political weapons used by the local intelligentsia in the local fight against imperialism.

Unlike previous poets in whose hands the language created through the purges of the Transylvanian School sounded awkward, Eminescu not only navigated with sophisticated ease the new waters of vocabulary, rhyme, and syntax, but he bestowed on language such attributes as 'sweetness', 'beauty', and 'experienced old age'. Making use of language as an instrument that purportedly proved the beauty of Romanian literature and history to the detriment of other cultures surrounding it, Eminescu shows a pronounced tendency towards the glorification and hyperbolization of Romanian culture that had overt xenophobic tendencies. Under the politically explicable threat of Austro-Hungarian domination in Transylvania and Bukovina, he makes clear in his political writings not only that the Romanian language is of superior calibre to Hungarian but that other languages (especially Finno-Ugric and Slavic) are downright uglier and distinctly unable to express the particular beauty of the superior 'Romanian soul'. The slander Eminescu subsequently unfurls against Hungarian has frighteningly racial overtones: 'The language? They should be ashamed of it. Its sounds can terrify stones.' Unsurprisingly, this is extrapolated to politics: 'Whose servants should we be? Those of the most decayed population in Europe, whose vanity and bragging is but a long and disgusting Donquixotism? What do these people have that makes them superior to us? [...] Do they have a language?' (Eminescu 1990: 22)

Not only are all Eminescu's predecessors, irrespective of rank and file, equally sanctified as heroes of the Romanian language (Cantemir is accorded roughly the same space as Barbu Mumuleanu and Alexandru Sihleanu, naïve debutants in poetry), but, according to Eminescu, the bare fact that they write in Romanian automatically allows them to enter into the monumental pantheon of Romanian literature.

Eminescu's self-professed gift is to use the purported Romanian exceptionality (which is stressed to the point of obsession both in poetry and in his political writings) to create a poetic language never before heard in Romanian discourses. In 
the folktale-turned-love poem, Călin file din poveste, Eminescu parades some of his most obsessive and representative motifs: nature meets libido in a purified, virginal, spotlessly natural milieu replete with romantic favourites such as moonlit forests, ruined castles, and the feminine element in various unavailable but voluptuous guises. Out of this marriage of folk tradition and natural elements, Eminescu creates a utopic universe, which, just like language was able to cradle the Romanian soul from generations past, features nature as a protective womb against the ills of modernity. The language in this strangely haunting love poem reaches a paroxysm of lyricism and romantic melody unparalleled in Romanian literature:

When on my breast you lean your head feeling my heart's enamoured beat / And I in passion press my lips upon your rounded shoulder sweet; / And when our thirsty lips unite, I drink thy breath into my soul, / Our hearts grown heavy in our breasts, that each the other's pain console. (Eminescu, Călin) ${ }^{7}$

Eminescu's linguistic gift comes at a hefty prize, however. If ethnicity did not find a way into Eminescu's poetry until late, when it did in The Third Epistle it did so with a bang. Identifying and vilifying foreigners as enemies of the Romanian people in the smoothest-sounding xenophobic discourse ever written in Romanian verse, Eminescu lashes out at the Other with unrestrained ferociousness:

As sly as artful foxes will they the benches throng / Frenetically applauding our country game and song; / Then meeting in the Senate each other's praises speak / This heavy-throated Bulgar, that long and hook-nosed Greek. / Each claims to be Romanian, whatever mask he wears, / These Bulgo-Greeks pretending that they are Trajan's heirs; / This poison froth, this dung-heap, this foul and filthy brood / Have they indeed inherited our nation's master hood ! [...] Until at last these nothings, this foul and loath full scum, / These cripple-minded stammerers lords of our land become. (Eminescu, The Third Epistle)

When confronted with the challenging political difficulties that the Romanian Principalities were facing in the late $19^{\text {th }}$ century, Eminescu invariably reverted to autocratic authoritarianism. This comes as a surprise especially in the context where the poet abhorred the tyranny of the Austro-Hungarians oppressing the Romanians of Transylvania. Despite this, at the end of The Third Epistle, the poet does not hesitate to invoke bloodthirsty warlords of the self-styled 'glorious' Romanian past such as Vlad Țepeş (the infamous Dracula), whom Eminescu summons to purge the country of its ethnic 'filth', which had 'shamed' the ancestors, the language, and the Romanian traditions. As Antohi warns, Eminescu's use of history is always

$7 \quad$ All translations from Eminescu's political writings belong to the author. Those from his poetry belong to Corneliu Popescu. 
'contaminated by utopian and mythical elements' (Antohi 1999: 123), which, in agreement with Cohen's writings on history, reinterpret, resituate, and embellish the past in accordance with the 'narrativizing' demanded by the ideology of the day.

Cantemir's acceptance of a mixture of ethnicities making up the evasive concept of the 'Romanian people' has by now been entirely disposed of and replaced by that of purity understood as a lack of interference in the language and peaceable activities of Romanians by outside elements. The Bulgar and the Greek filth have been joined by ‘the crooked-face Găgăuz' (sacrificed from Popescu's translation), and, of course, by the omnipresent Jew, who figures relentlessly in Eminescu's political writings as the primordial threat to Romanians everywhere, however, nowhere as melodious as in this example of poetic racist slur.

In practice, Eminescu differs little from the politically motivated enlightenment theorists predating him. Like them, subsuming language to his political aims, he dreams of recreating the mesmerizing feel of ancestral Dacia (which Cantemir equally praised for its quasi-mythical properties) and of returning to an ancestral linguistic and social order. Seen in his verse as the golden age of Romanian civilization, this mystified order would contribute to the resurgence of the Daco-Roman continuity theory and, as we shall see, its employment in more drastic ideological platforms. And if language is indeed the ideological vehicle for this manoeuvre, its enabling agent is the peasantry.

If Cantemir sees the peasants as the least representative elements of Romanianism in the gamut of social organization, Eminescu comes to idolatrize the peasants and to make out of them the single bearers of the torch of purity. Eminescu cannot conceive of a different political orientation for Romania but a return to traditionalism, ruralism, and a 'real' language, which should not be mixed with foreign elements. Could Eminescu have been deceiving himself so much as to ignore that the 'real' language, as even Cantemir acknowledged, was even more interspersed with Slavicisms and Graecisms than the one spoken in the $19^{\text {th }}$ century?

Confirming Eminescu's political short-sightedness, Garabet Ibrăileanu attests that Eminescu '... cannot conceive of another state but the past' and is unable to put together an objective forecast for the future (Ibrăileanu 1970: 48). Later exegetes are able to identify in Eminescu an evident fear of the present based on the fact that he attacked and was afraid of modernity (Drace-Francis 2013: 174), as if he were part of a minority himself (Drace-Francis 2013: 184).

Indeed, save for a psychoanalytical exploration of his discourse, we shall probably never know what Eminescu was practically afraid of when he was lashing out at modernity. However, multiple elements from both his poetic and political discourses hint at anxiety in relation to foreign elements penetrating the language and point to a psychotic, schizoid personality, which, given his frequent hospitalizations in later years for 'madness' might suggest an unstable psychology. 
In support of this view, Ibrăileanu claims that Eminescu went through several different ideological phases contingent on his geographical positioning at the time. In the beginning, he took a Maiorescian approach, refusing an 'absolute purification', as to purify the language of all its foreign elements would have meant to 'tear out the entire fabric in order to take them out' (qtd. in Ibăileanu: 41). This is in line with Maiorescu's thinking that 'the purity of the language is an unjust demand which could nowhere be realized' (Maiorescu 1966: 140), as well as with Alecu Russo's impassioned plea against the surplus Latinization and destruction of the language (Ibrăileanu 1970: 23).

However, Ibrăileanu claims that later Eminescu disagreed with his protector as well as with the fact that the Transylvanian School's writers 'falsified historical truth' (Maiorescu 1966: 79) through their Latinizing of the language, ending up disagreeing again with Maiorescu's warning that 'a people cannot live with a falsified culture' (Ibrăileanu 1970: 83). Instead, later Eminescu became an ardent supporter of his earlier teacher, Aron Pumnul, who maintained that '... just as a body without soul is dead, so is the nation dead without language' (Pumnul qtd. in DraceFrancis 2013: 163) and who militated for a thorough cleansing of Romanian of all its Greek and Slavic elements and for a Latinization of the current vocabulary that made the language sound nothing short of ridiculous (Maiorescu 1966: 142). What Eminescu's position-shifting proves is that his approach to linguistics was entirely speculative. Instead of following a systematic language-based analytical approach, he was content to take the opposite position, namely to follow the political stand of earlier theorists such as Cantemir and the Transylvanian School's writers, and, without criticizing their theories on exceptionality, blindly to apply their concepts of the 'noble lineage' to a language to which he added the poetic valence of 'beauty'.

It is in this form and at this precise moment that a new notion of Romanian identity started to be born out of the efforts of post-Eminescian ideologues eager to perpetuate the attributes of the 'beauty' of the language and the greatness of the past, both concepts exceedingly dear to Eminescu. However, this identity, based as it was on speculative argumentation, is hardly scientific and features common misconceptions and empty markers such as 'greatness', 'nobility', and 'beauty', which are used as umbrella notions to cover the hole left open by the vague national identity. It is here that Greenfeld's theory, which sees nationalism as a glorification of past nobility, applies to the romantic-nationalist moment in Romanian historiography: What used to be a mixed language of Latin descent and a mixed race becomes with Eminescu (himself of mixed origins) a pure language and a pure race whose purest representatives are (ironically) the peasants, whom Eminescu chooses to worship.

Another difference needs to be pointed out in the movement from ethnic consciousness to the future national state. Despite Cantemir's less biased approach to history, the concept that struck a deep chord with his followers in the $19^{\text {th }}$ century was that of the 'Romanian exception'. According to Cantemir, this is the view that, 
unlike the rest of the Europeans who trace their roots back solely to barbarians, the Romanians, through virtue of their Latin heritage, are the only real descendants of the 'illustrious Romans' (Cantemir qtd. in Lemny 2009: 133). Although Lemny calls this statement 'très discutable', this does not stop him from excusing Cantemir of naïveté on the basis of the latter's need to popularize knowledge of his people, otherwise ‘très peu connu en Europe' (Lemny 2009: 133).

Cantemir justifies this exceptionality both through the language argument (a Latin people surrounded by Slavic and Finno-Ugric neighbours) and through Moldavian and Wallachian resistance to Muslim conquest, which he sees as superior to that of the surrounding Bulgarians, Hungarians, Serbs, and Greeks, who accepted Turkish occupation (Lemny 2009: 131). ${ }^{8}$ Ignoring that the Romanian territories were nominally under the jurisdiction of the Porte until 1877, this stance initiates a recurring historiographical practice which hinges on the heroism and audacity of the Romanian people. This is also the stance that empowers Eminescu's unparalleled glorification of the language and the nation, which, through the later dissemination of his poetry in mass education campaigns was going to drastically change the way Romanians saw themselves in the $20^{\text {th }}$ century.

\section{From Romantic Nationalism to Fascism}

In his attempt to define the concept of nationalism, Gellner makes use of Weber's definition of the nation-state. According to Webber, the state is 'that agency within society that possesses the monopoly of legitimate violence' (Gellner 1983: 3). Considering that subsequent critical theorists such as Foucault would develop the metaphor of the panopticon to describe the operation of power in the institution of the state, by invoking Weber's definition, Gellner stresses the connection between nationalism and violence. Although not in agreement with Gellner over the origins of nationalism, Breuilly also clearly states that 'nationalism is, above and beyond all else, about politics and that politics is about power' (Breuilly 1993: 1).

So far, we have traced the development of ethnic consciousness in Romanian cultural history from the $18^{\text {th }}$ to the $19^{\text {th }}$ century. The first part of the $20^{\text {th }}$ century would witness not only the establishment of the modern Romanian nation-state in 1918 but also the rise, in its aftermath, of the most violent form of Romanian nationalism. The Iron Guard, a domestic form of fascism inspired by Mussolini's 'fascia' movement (Schmitt 2017: 64) and Hitler's Nazism, which received financial backing from Nazi Germany (Webb 2008: 329), would become in the interwar period the self-styled guardian of tradition in the face of Semitic contagion of Romanian purity. The movement's ideologue, Corneliu Zelea Codreanu, would use among

8 The reason why he considered that the Romanian principalities preserved their independence in the face of Turkish invasion despite his forced exile to the court of the Russian Tsar is that the Ottomans did not rule themselves in the Romanian principalities but chose local rulers as representatives. 
others the uniqueness of the Romanian language to defend the values of Orthodoxy and nationalism and raise Romanianness to the status of a religious cult, in whose defence the use of violence was not only permitted but highly encouraged.

If historian Nicolae Iorga was proud to state at the end of the $19^{\text {th }}$ century about Eminescu that 'the poetic interpreter of the soul of an entire nation was finally born' (Iorga), the $20^{\text {th }}$ century clearly proved that the opposite was true. The treaties of Trianon and Versailles of 1919 almost doubled the territory of the new Romanian state, now called 'Greater Romania', because it was given the provinces of Bessarabia, Bukovina, Transylvania, parts of Banat and Dobruja (including Dobruja's Southern Quadrilateral, which Romania seized from Bulgaria after the Second Balkan War and whose population was only $20 \%$ Romanian). It did not matter to Romanian ideologues that the Paris accords enlarged Romania only to stem the expansion of Bolshevik Russia (MacMillan 2001: 125). Trianon was seen as the place where 'the centuries-old dream of Romanians' came true (Anghel 2016: 33-35).

According to historian Margaret MacMillan, the enlargement of Romania was mainly due to the impassioned pleas of Prime Minister Ionel Brătianu, whose curious pathos during the Paris conference (MacMillan 2001: 125) desperately tried to convince the Western powers that Romania is a Latin country which should be considered a sister of France. He explained that 'the Rumanian upper classes loved France: they bought educations in Paris for their children, and clothes and furniture for themselves'. What Brătianu did not mention was that 'the Rumanian aristocrats who spoke such beautiful French and who came to Paris to buy their clothes had portraits of their grandparents in caftans and turbans' (MacMillan 2001: 128). Despite the fact that, as MacMillan puts it, 'visitors to Rumania from Western Europe were struck by its exotic, even Oriental, flavor,' (MacMillan 2001: 129) Brătianu was schooled on the benches of romantic nationalism. He knew how to use Eminescu's nobility argument to convince Westerners that the Romanians 'were the heirs of the Roman empire, part of Western civilization. Conveniently for the peace negotiations, [the Romanians] could argue that all the old Roman province of Dacia including part of Transylvania, which belonged to Hungary, should be restored to them' (MacMillan 2001: 128). Although Brătianu's rhetoric was considered pathetic by members of the British delegation (Harold Nicolson considered him a 'humbug' who 'catches his own profile in the glass') (MacMillan 2001: 126), Romania's position as a 'useful buffer' between Europe and Russia forced the allies to take a conciliatory position on Brătianu's 'excessive' territorial demands, even though Romania was a 'notoriously unreliable' wartime ally (MacMillan 2001: 128).

Brătianu's victory at the Paris conference gave an unprecedented boost to a new discourse focused on unity and indivisibility. What interwar nationalist ideologues ignored, however, was that the celebrated state that gave a new home to all Romanians also comprised almost 30\% non-Romanian speakers (Antohi 2000: 69). ${ }^{9}$

9 Sorin Antohi puts the figure at $28 \%$. 
As Adrian Webb put it, this meant that the discourse that 'stressed on the unity of one people implied its lack of unity with any other people' (Webb 2008: 15). Czech journalist Walter Kolarz also warned later in 1946 that the 'life and happiness of one country and people meant death and disaster for the other' (Kolarz 1946: 104). It was obvious in the aftermath of what was termed 'The Great Union' that Romanians would have difficulty cohabitating with Jewish, Magyar, Ukrainian, Bulgarian, and Turkish ethnics, whom the 1919 Treaty of Trianon suddenly designated as Romanian citizens. Ironically, these were exactly the same ethnicities that Eminescu lambasted in his impassioned xenophobic discourse some four decades prior. The presence of such a large contingent of foreign ethnics who did not speak Romanian in 1919 led to a resurgence of the cult of the language, as Romanians perceived the foreigners as a threat to the confused sense of identity they derived from the sudden and unexpected unification. As Antohi also acknowledges, this inculcated a sense of identity crisis in the new Romanian state, which rushed through a process of Romanianization policies, 'thus betraying the spirit of the Paris Treaties, and the tolerant program of Transylvanian Romanian elites who, upon agreeing to join the Romanian Kingdom, had insisted that substantial minority rights be guaranteed' (Antohi 2000: 69).

In line with Nietzsche's innocent call for the a posteriori re-creation of a past that is different from the historical one, Romanian nationalism reinterpreted history for its own benefit and with tragic consequences. Designating the Jews as the most dangerous of the ethnicity that made up a third of 'Greater Romania', Corneliu Zelea-Codreanu wrote in 1936: 'We face a Judaic State, an army that comes into our land to conquer us. Jewish population movements are effected against Romania according to a well-established plan. [...] Where is the naive person who can believe that the population movements of Jewish masses occur unplanned?' (Codreanu 2011[1936]: 81). A devotee of Eminescu, Codreanu hailed from a Bukovinian family of mixed ethnic heritage, like that of the poet himself. His father, a German teacher and Romanian nationalist ideologue, changed his name in 1902 from the PolishUkrainian Zelinski to the more Romanian-sounding 'Codreanu'10 (Schmitt 2017: 37).

Not even a decade after the Paris treaties, Corneliu Codreanu became the charismatic leader of the Iron Guard, one of Europe's most fanatical fascist organizations, also known as the Legion of the Archangel Michael or the Legionary Movement, which fought on ultra-religious nationalist lines for the purification of the Romanian nation of all foreign influences, primarily Jewish. It is undisputed that Codreanu's far-right ideology borrowed massively from Eminescu's political writings. In his autobiography For My Legionaries, Codreanu lists the poet among 'the great men of Romania of 1879' and quotes Eminescu as asking: 'By what labors or sacrifices have [the Jews] won for themselves the right to aspire to equality with the Romanian people? Was it they who fought the Turks, Tartars, Poles, and Hungarians? [...] Was it through their efforts that the fame of this country spread, that this language was disinterred from the veilings

10 In Romanian, the word codru means 'forest', wherefore Codreanu would translate as 'of the forest'. 
of the past? Was it through one of them that the Romanian people won its right to sunlight?' (Eminescu qtd. in Codreanu (2011[1936]: 76). If many academic studies emphasized the legionaries' fanaticism and devotion to both right-wing extremism and the Romanian Orthodox religion (Schmitt 2017), Romanian studies scholar Alex Drace-Francis is the last in a series of academics to uphold the view that '.. the legionaries' cult of sacrifice in the name of the nation came not only from Orthodox theology, nor yet from concepts of fatality in Romanian folk literature, but also, and possibly predominantly, from Eminescu himself' (Drace-Francis 2013: 176).

The evolving of nationalism into fascism has been thoroughly discussed by a wide variety of scholars, and the relationship between the two ideologies has been confirmed, with fascism seen as a backlash against the effect modernity had on a mainly traditional Europe. Nationalism scholar Daniele Conversi writes that "Nazism transformed the "traumatic modernism" resulting from the abrupt irruption of modernity and the decline of traditional lifestyles into a redemptive mission informed by an eschatological longing and technocratic idolatry' (Conversi 2012: 23). Weber's prophetic dictum that the modern nation-state possessed a monopoly on violence would prove true in Romania when Codreanu's movement grew stronger after his death in 1938 to pronounce the birth of the Legionary Romanian State in 1940. The short-lived state (it was abrogated in 1941) would spawn the even more violent dictatorship of Marshal Ion Antonescu - the de facto inheritor of the now suppressed Legionary Movement -, who declared in 1941 that Romania would 'march without hesitation on the side of the great Führer and Duce' (Webb 2008: 160). Started in the name of national reunification, Antonescu's war against the Soviets on the side of Nazi Germany would lead to the temporary recovery of eastern territories, which, ironically, Hitler himself had given away to Stalin in the Ribbentrop-Molotov Pact two years earlier. The Nazi-Soviet pact was further grounded in the fact that the award of the disputed region of Bessarabia to Romania in 1919 was never ratified at the Paris conference due to the opposition of the United States and Britain (Anghel 2016: 39). This made Russia (and later the Soviet Union) the de jure owner of the province since 1812, when it was ceded to the Tsar by the Ottoman Empire in the Treaty of Bucharest.

Nevertheless, the invasion of the Soviet Union would put Romania in control of the Transnistria Governorate for three years, during which historian Andrei Oişteanu asserts that thousands of Jews and Gypsies deported there from Romania died (Oişteanu 2009: 67). Mirroring Brătianu's demands on parts of Hungary two decades earlier: during WWII, the Romanian army came into control of territories that had never been Romanian, nor did they have a majority Romanian-speaking population. In Transnistria, speakers of Romanian stood at around 8\%. This did not stop Antonescu, in a gesture of brutal cruelty enacted during his eastward advance, to order in October 1941 that approximately 25,000 Jews be 'shot to death, burned alive, or hung in the streets of Odessa' (Oişteanu 2009: 323). 
Romania's loss of Transnistria and the retaking of Bessarabia by the Soviets in 1944 during the second Jassy-Kishinev offensive can hardly be seen - in the light of Romania's Nazi invasion of the Soviet Union - as unfair. To stress the illegitimate Russian occupation of the region after the Treaty of Bucharest and its 'imperial rule' by Russia since 1812 (Caşu 2015: 347, 351), the nationalist ideology whitewashes the role played by fascist Romania during WWII. The self-victimizing Romanian attitude in the purported loss of Bessarabia at the end of the war is predicated on a type of discourse inherited from romantic nationalism and solidified by the fascist period.

If - to paraphrase Nietzsche - modernity sought the erasure of a history it claimed to improve, this led to the even more dangerous emergence of fascism as the apex of modernity's unwanted side-effects. In tracing the evolution of nationalism from the enlightenment to the $20^{\text {th }}$ century in Romania, it is important to emphasize the role that language progressively played in defining ethnicity and Romania's relation to other nationalities. The lack of scientific rigour with which linguistic practices were treated during this time, from Cantemir's naïve mistakes to Eminescu's emphatic exaggerations, instilled a methodology of politically-motivated amateurism that would facilitate the elaboration of a racist discourse which saw ethnic Romanians as superior to about a third of their non-Romanian co-nationals after WWI. Moreover, the new nationalist ideology focusing on the union of all Romanians in a single state would assure the survival of 'Greater Romania' for 20 years and would provide the nostalgic call for reunification (reîntregire) that would resound in nationalist ears throughout the national-communist and post-socialist periods. During this time, Romanian identity remained a confused concept and continued to slide to the right of the political spectrum even after the establishment of Marxism-Leninism and the official rule of the country by the communist regime.

\section{National Communism}

As early as 1957, former communist revolutionary and Deputy Prime Minister of Yugoslavia, Milovan Djilas, who was ousted from Tito's government in 1954, asserted that the national component of the communist revolutions took over their erstwhile internationalist character, and although Lenin, Stalin, Trotsky, and Bukharin all 'expected that the state would rapidly wither away, that democracy would be strengthened', in actuality 'the reverse happened' (Djilas: 37). Although Djilas made no mention of it, it was nationalism that destroyed the initial goals of internationalist socialism, or, as Katherine Verdery puts it, 'although the early years of socialist internationalism suppressed [the nationalist] discourse, it gradually crept back in’ (Verdery 1993: 181). Peter Zwick argued in 1983 that this transformation allowed communism to survive and that 'whatever vitality persists in contemporary communism actually derives from its national orientations' (Zwick 
1983: 2). Another way to look at the situation with the hindsight allowed by the regime's demise in 1989 is to admit that communism failed precisely because in all the countries where it once ruled it transformed into nationalism.

The advance of communist power in post-war Romania in the late 1940s promised to right many of the wrongs committed by nationalism and fascism. In terms of language, in a sudden re-orientation of cultural discourse to the left, the early communists were eager to stress the Slavic connections between Romanian and Russian. Russian became a mandatory (yet unpopular) subject in secondary schools, and linguists pointed out the affinities between Romanian and its Slavic counterparts. The Daco-Roman continuity discourse was temporarily halted, while historical accounts mentioned the Romanians as once strongly connected with their Eastern European neighbours. Yet, in a situation that paralleled political developments signalling cooling relations with Moscow, Russian language and the pro-Russian orientation gradually fell out of favour with the Romanian communist officials by 1965 to be replaced by an inward-looking, self-celebrating discourse.

The context was made possible by Khrushchev's denunciations of Stalin's crimes in 1956, which marked a turn in all satellite country politics. Petrescu argues that, confronted with Soviet de-Stalinization, Gheorghe Gheorghiu-Dej, prime secretary of the party at the time, realized that 'national identity is a crucial social and political resource ... to ensure [the party's] political survival' and 'after 1956, the Romanian Stalinist elite engaged cautiously in a process of "community building"' (Petrescu 2009: 402). In tune with the newfound nationalist course, this community was to be purged of Semitic elements. The anti-Semitic purges of the early 1950s initially copied Stalin's own. After Ana Pauker and other hard-line Stalinists were ousted from leadership, however, the purges were seen as another means to reinforce the nationalistic course, which culminated in the retreat of the Soviet army from the country in 1958.

Another episode contributing to the Bucharest-Moscow split occurred in 1962, when Khrushchev mused on instating a bloc-wide economic policy that would have a strong nationalist backlash: He proposed that satellite countries specialize in various fields of production that befitted their industrial contexts. This drew heavy criticism from Dej and a young Nicolae Ceauşescu, who saw the policy as an attempt to subordinate Romania's primarily agricultural production to Soviet economic and political interests (Kemp 1999: 149).

Nicolae Ceauşescu merely continued Dej's policies when he took over in 1965, and he remained committed to make Romania increasingly independent from the Soviets. While this may have been a courageous act in the beginning (as it was when he denounced the Soviet invasion of Czechoslovakia in 1968), the unexpected result was the isolation of the country and its turning into an increasingly powerful bastion of nationalism from the late 1960s onwards. Verdery states about this period that 'national interests gave ready expression to 
the anti-imperial feelings of many East Europeans ... against Soviet or Russian domination' (Verdery 1993: 181). Indeed, as journalist Henry Shapiro put it upon his visit to Bucharest in 1965, 'ideologically, the Romanian leaders remain hard line Marxist Communists, but it appears to be a communism neither of Moscow nor Peking style, but strictly national Romanian' (Shapiro 1965).

If fascist ideologues such as Radu Gyr or Nichifor Crainic were imprisoned in the 1950s, the 1964 amnesty allowed them to progressively return to cultural life and hold leading or contributing roles in nationalist publications such as Glasul patriei. Similarly, of the names listed as forbidden by the communists in 1945, which included among others Titu Maiorescu, Garabet Ibrăileanu, Ion Heliade Rădulescu, Octavian Goga, and Nicolae Bălcescu - who were considered of a nationalist orientation and therefore in disagreement with the goals of internationalist communism -, all would be rehabilitated in the 1960s (Tismăneanu: 490). Moreover, these writers and the nationalist ideology they promoted would entirely replace the early communists' pro-Russian/internationalist orientation, becoming the foremost representatives of Romanian nationalism in the 1980s.

Anthropologist Katherine Verdery states that during Ceauşescu's rule the Communist Party incorporated nationalist ideology into its policies in order to strengthen its political position. It was also for its domination of political life, Verdery claims, that the party co-opted all Romanian intellectuals, regardless of political orientation, to take part in the administrative apparatus (Verdery 1991: 310). She also states that the lack of opposition to the regime that was perceivable in late socialist Romania, unlike in other countries of the Bloc, was due to the mollification of the intellectuals by the regime, as the Party offered writers an outlet of expression for their nationalist tendencies and fervent promotion of the concept of the 'nation' (Verdery 1991: 312). It was therefore the nationalist intellectuals' own participation in the communist state apparatus that generated the transformation of internationalism into national communism because '.... the Nation was so well entrenched discursively in Romanian life. It was the one subject that was guaranteed to get Romanians' attention, because so many of them were using it themselves' (Verdery 1991: 125).

Eminescu's name, having topped the list of forbidden writers in the 1940s, would not only return to prominence after 1965 as well but would come to completely dominate the new nationalist cultural course. Ironically, Eminescu's vituperative xenophobia and nationalism, which powerfully influenced fascist ideology, impacted the programme of national communism to the extreme although his political writings were not made public. Not only was Eminescu's nationalism allowed to flourish during the second part of the socialist period, but for the better part of the $20^{\text {th }}$ century Eminescu's cult was elevated to second rank after Ceauşescu's own through what historian Lucian Boia called the 'tyrannical effect' of 'the Eminescian musicality' whose 'spell [...] Romanians have been under [...] for more than a century’ (Boia 2001: 244). 
If early $20^{\text {th }}$-century nationalist ideologues, such as Nicolae Iorga, condensed the soul of the nation into Eminescu's poetry, or rather manufactured this soul under Eminescu's authority as the national poet, the communist ideologues returned to this very image at the end of the regime in order to promote a nationalistic version of communism which had nothing to do with Marxism. Indeed, a new ideology of the 'Romanian soul', or Romanianism, was born in the 1980s, which was fed to the Romanian psyche in the image of Eminescu. As Lucian Boia puts it, 'a portrait from his early youth is imprinted on the retina of every Romanian’ (Boia 2001: 244). Even right-leaning critics such as George Călinescu did not shy from stating that '[...] Eminescu becomes after his death, through an equally violent exaggeration of [his] cult [...] the beginning and end of each and every discipline, the supreme authority, the all-knowing one' (Călinescu qtd. in Drace-Francis 2013: 183).

Comparative literature scholar Călin Mihailescu claims that the same portrait referenced by Boia 'has grown a mythical halo coincident with the country's symbolic borders, and its culture's claim to universal recognition', thus merging Eminescu's poetic and political discourses into a nationalist spirit that was gradually introduced in the Romanian public opinion, ever more strongly, and that turned Eminescu into a quasi-sanctified figure. Alongside Eminescu's deification by late communism, Romanian language would reclaim its 'musicality' and 'beauty' and with these attributes a return to the glorification of Latin descent and the DacoRoman continuity theories. This political move not only obscured once again the nebulous origins of the Romanian language and Romanian ethnicity, but it instated a veritable taboo on research contravening the ideologically-sanctioned discourse. With language reacquiring its sanctified status in the guise of poetic beauty, Eminescu's highly speculative argumentation, which up to his time was still only a theoretical framework, becomes - helped by favourable political circumstances in late communism - an official political line.

The Eminescu moment is therefore not only the finis coronat opus of the laborious work of language theorists toiling to find a continuous identity for the disparate and mixed Romanian heritage reflected both in the language and the ethnic make-up of the country in the $19^{\text {th }}$ century. Eminescu also managed to superbly fill the identitarian void that plagued Romanian modernity with the most admirable filling there was: poetic language. It is in this manner that we should understand Benedict Anderson's claim about the shaping of the imaginary community in Romania: Having found an efficient resolution for their identity crisis, Romanians proceeded to identify both with Eminescu's poetry and the reaffirmation of the Latin character of Romanian language. Out of these ingredients, they were then free to manufacture the 'Romanian soul'.

Moreover, as Verdery attests, 'the national and self identity of many Romanians emphasizes unjust suffering' (Verdery 1993: 196). This closely parallels the way in which, as Cohen would put it, Eminescu's biography was spun in both socialism 
and post-socialism: the poet never enjoyed the fruits of his hard-earned labour, was mostly poor and destitute, and his life was one 'of suffering, of the misunderstood genius struck down by insanity at the age of only 33' (Boia 2001: 244). It is easy for the national psyche to identify with the image of self-martyrdom because 'all across the region, local historiographies represented nations as innocent victims' and 'historians have presented their nations as suffering for the salvation of western civilization, sacrificed on an Ottoman altar so that the glory of western Christendom might endure' (Verdery 1993: 196). By the most recognizable figure of the 'Romanian Soul', self-martyrdom appealed even more strongly to Romanian national imagination when, in post-socialism, various writers and public political figures spread conspiracy theories involving Eminescu in alleged murder plots following which the poet was 'killed at the order of the Freemason movement' (Coja 2011), 'politically detained' (Zamfirache), or murdered by 'the Romanian state, who signed a secret alliance with Germany and Austria-Hungary in 1883' (Țene 2017).

In this case, it is less Gellner's theory on nationalism, which looks primarily at the socio-economic conditions necessary for its emergence in the $19^{\text {th }}$ century, and more Greenfeld's one that applies to the Romanian case. With an industry and agriculture that were barely embryonic in the $19^{\text {th }}$ century, it was culture that Romania promoted as a marker of its identity (and as Greenfeld would say, nobility) in the period of romantic nationalism. However, unlike Greenfeld, who sees the nation as an organic product created after the elite model in the late middle-ages, Romanian identitary discourses retroactively and self-consciously stressed the importance of the Romanian middle ages (mainly by focusing on historical figures, local rulers, and despots) during the enlightenment and romantic periods, thus leading to the emergence and stabilization of the nationalist discourse per se in the $20^{\text {th }}$ century.

\section{Post-Socialism and Conclusions}

Even though Zygmunt Bauman states that 'the collapse of communism was the final nail in the coffin of the modern ambitions which drew the horizon of European... history of the last two centuries' (Bauman 1992: xxv), the perpetuation of the enlightenment-romantic-fascist-national-communist discourse into the postsocialist era tends to prove him wrong. It would be too early to state that the postsocialist world is 'a world without a collective utopia', as the Polish sociologist argues (Bauman 1992: xxv). Instead of reappraising the past at its right value, the attempt to give the Romanian people - paraphrasing Nietzsche - a different past from the one it hails from seems to have reached new extremes in post-socialism.

If odes to the Romanian language were as common during socialism as those dedicated to the 'father of the nation' himself, the post-socialist intellectuals only 
expunged from their vocabulary the presence of communist leaders, preserving its highly nationalistic character. Intellectuals privileged by the communist regime would return to the sanctity of the language after the 1989 revolution. Adrian Păunescu, one of communist Romania's most recognizable cultural figures, would declare in an interview in 2010, the year of his death, that Romanian did not disappear as a language like others around it because it borrowed freely from Magyar, Slavic languages, Turkish, and Greek. While we see with Păunescu a certain return to Cantemir's mixed linguistic character, Eminescu still represents for the socialist-era poet the 'propping structure of the nation'. Interestingly, Păunescu also refers to Eminescu's influence as both 'luck and divine condemnation', which helps Romanians, unlike other people, 'recognize each other and identify with him' (Păunescu 2010).

The continuing sanctification ofEminescu's name, coupled with what Verdery calls 'the post-revolutionary vogue for prison memoirs', which in her view 'contributed further to [the] sense of a history of national victims' (Verdery 1993: 196), would suddenly affirm not only the anti-communism of the socialist-era intelligentsia but also their unwavering dedication to the national project after 1989. Furthermore, the choice of the political union between Transylvania and the Kingdom of Romania as the country's national day since 1990 as well as the pronouncement of a 'Romanian language day' in 2013 by the centre-right government of Traian Băsescu point to an increasingly closer relationship between language and national identity. Post-socialism also saw an abrupt revalorization of the interwar period, whitewashed of its fascist character. Despite the fact that, as Antohi phrases it, "the interwar European Zeitgeist and political practices were not exactly favorable to non-ethnic political contracts, or nonethnic collective identities' (Antohi 2000: 69), the period acquired in post-socialism the aura of another golden age, possibly seen as secondary in character only to Eminescu's idealized Dacia. Moreover, to return to linguistic practices, in post-socialism etymologies which had been gradually inched in the direction of realistic definitions during socialism - as we have seen in the afore-mentioned case of the dictionary published by the Romanian Academy started to be reverted to forms that were re-purified of their Slavic references.

Finally, Verdery claims that in post-socialism 'the meaning of "nation" has shifted:' if it ever was affected at all by communist ideology (although this is debatable), its meaning in post-socialism has re-become ethnic. Even if their regimes are no more, the nationalist, fascist, and national communist ideologies did not fail in their endeavour to reinterpret history. What seems to endure after the successive changes in Romanian administrations is Cohen's statement that every generation is willing to 'spin its own tale' based on its own understanding of the past. Nationalism has all the ingredients to provide a consumerist-type identitarian discourse, which no capitalist consumer would find easy to ditch.

In conclusion, it is not far-fetched to state that the totalitarianism of nationalism in Romania has been more penetrating than that of communist ideology and that 
post-socialist society has institutionalized nationalism as a constitutional right of the predominating ethnicity in the country. This is also the argument of Ioana Lungu, who, referencing the language of the 1991 'flawed constitution' (Lungu 2002: 410), argues that all the Eastern European constitutions after 1989 are defined by 'a pronounced concern for national identity' (Lungu: 399). Quoting Robert Heyden, Lungu makes the case that Romanian ethnicity is identified as a 'sovereign being with its own defining language, culture and perhaps "biological essence", which must be defended at any cost' (Heyden qtd. in Lungu 2002: 399). This gives Romania's neoliberalism a profound totalitarian character that is entrenched in its only apparently democratic covering.

Under communism, culture became synonymous with 'nation' because it proved easier (and, as Verdery argues, beneficial for the government) to incorporate nationalism into the goals of a revised version of communism than to get rid of it. Its incorporation, however, helped legitimize Cantemir's naïve linguistic mistakes from the $18^{\text {th }}$ century and validate the discourse that made those mistakes part of dubious nationalistic practices. Going further in time, even though Eminescu popularized Cantemir's Daco-Roman ideology and Latin-descent theory in his unparalleled poetic achievements, it is the later promoters of nationalism based on Eminescu's discourse that dealt a staggering blow to scientific rigour by enforcing the assimilation of such attributes as 'beauty' and 'melody' into the nationalistic discourses of the $20^{\text {th }}$ and even $21^{\text {st }}$ centuries. Far from diminishing the positive influence that first Cantemir and later Eminescu had on the development of cultural life and literature inside as well as outside Romanian national borders, it is important to address the contributions they had to the instatement of language as a political tool used for the continuing support of Romanian nationalism.

If Nietzsche found a certain degree of abuse of history positive for creating a more acceptable version of modernity, one that overlooked the ignoble and criminal past from which humanity hailed, his pronouncement has all the more chances to appeal to a nation submerged in a fictitious sense of self-identity, like the one of the Romanians. As I have argued here, romantic nationalism, fascism, and the national communist regime, in their attempt to purge the Romanian language and the Romanian ethnie of foreign elements, misread historical evidence in favour of a discourse meant to attribute Romanians a nobility they did not possess. If, as Greenfeld contends, this is not an isolated case in the history of European nationalisms, it is also a potentially dangerous endeavour which Greenfeld, whose theory is indeed applicable to Romanian nation-making practices, does not necessarily address. As long as this nationalism prevails, the possibility of overcoming Romania's romantic attachment to exceptionality, beauty, and superiority remains minimal. This will only perpetuate the identity crisis which plagued linguistic and ethnic discourses from Cantemir and Eminescu to the tragedies of the $20^{\text {th }}$ century and for an unforeseeable time into the future. 


\section{References}

ACADEMIA ROMÂNĂ. 2010. Dicționarul Limbii Române. Bucharest: Editura Univers Enciclopedic.

ANDERSON, Benedict. 1983. Imagined Communities: Reflections on the Origin and Spread of Nationalism. London: Verso.

ANGHEL, Ion M. 2016. The Borders of Greater Romania. Annals of the Academy of Romanian Scientists. Series on History and Archaeology 8(1): 31-49.

ANTOHI, Sorin. 1999. Civitas Imaginalis: Istorie şi utopie în cultura română. Iaşi: Polirom.

2000. Habits of the Mind: Europe’s Post-1989 Symbolic Geographies. In: Antohi, Sorin-Tismaneanu, Vladimir (eds), Between Past and Future: The Revolutions of 1989 and Their Aftermath. Budapest: Central European Press.

BAUMAN, Zygmunt. 1992. Intimations of Postmodernity. London-New York: Routledge.

BOIA, Lucian. 2001. Romania: Borderland of Europe. London: Reaktion Books.

BREBAN, Vasile. 1987. Dicționar general al limbii române. Bucharest: Ed. Enciclopedică.

BREUILLY, John. 1993. Nationalism and the State. Manchester: Manchester University Press.

CANTEMIR, Dimitrie. 1717. Hronicul vechimei a romano-moldo-vlahilor. Sanct Petersburg. Reproduced on the website of the Academia de Ştiințe a Moldovei: http://cantemir.asm.md/files/u1/hronicul_vechimei_a_romano_moldo_vlahilor_ vol_I.pdf (last accessed: December 2021; my translation).

1933. Descriptio Moldaviae (transl. Gheorghe Adamescu). Bucharest: Cartea Românească.

CAŞU, Igor. 2015. Moldova under the Soviet Communist Regime: History and Memory. In: Tismaneanu, Vladimir-Iacob, Bogdan C. (eds), Remembrance, History, and Justice. Coming to Terms with Traumatic Pasts in Democratic Societies. Budapest: Central European University Press.

CIORANESCU, Alejandro. 1966. Diccionario Etimologico Rumano. Canarias: Universidad de La Laguna.

CLOSE, Elizabeth. 1974. The Development of Modern Romanian: Linguistic Theory and Practice in Muntenia 1821-1838. London: Oxford University Press.

CODREANU, Corneliu Zelea. 2011 [1936]. For My Legionaries: https://archive.org/ details/ForMyLegionaries (last accessed: December 2021).

COHEN, Paul. 1998. History in Three Keys: The Boxers as Event, Experience, and Myth. New York: Columbia University Press.

COJA, Ion. 2011. Marele patriot Mihai Eminescu, un martir ucis la comanda francmasoneriei. Personal blog. https://ioncoja.ro/marele-patriot-mihai- 
eminescu-un-martir-ucis-la-comanda-francmasoneriei/ 27 January. (last accessed: 3 December 2021).

CONVERSI, Daniele. 2012. Modernism and Nationalism. Journal of Political Ideologies 17(1): 13-34.

DJILAS, Milovan. 1957. The New Class: An Analysis of the Communist System. London: Thames and Hudson.

DRACE-FRANCIS, Alex. 2013. The Traditions of Invention: Romanian Ethnic and Social Stereotypes in Historical Context. Leiden-Boston: Brill Academic Publishers.

EMINESCU, Mihai. 1990. Publicistică. Referiri istorice şi istoriografice. Chişinău: Editura Cartea Moldovenească.

n. d. Epigonii. Luceafarul. Scrisoarea a treia. Călin file din poveste (transl. by Corneliu Popescu: http://www.gabrielditu.com/eminescu/contents.asp) (last accessed: May 2014).

GELLNER, Ernest. 1983. Nations and Nationalism. Oxford: Basil Blackwell.

GREENFELD, Liah. 1992. Nationalism: Five Roads to Modernity. CambridgeLondon: Harvard University Press.

HEGEL, Georg Wilhelm Friedrich. 1998. Phenomenology of Spirit. Delhi: Motilal Banarsidass. (transl. by Miller, A. V.)

HERDER, Johann Gottfried von. 2002. Philosophical Writings. Cambridge: Cambridge University Press.

HITCHINS, Keith. 1996. The Romanians. 1774-1866. Oxford: Calderon Press.

HOBSBAWM, Eric. 1983. Introduction: Inventing Traditions. In: Hobsbawm, Eric-Ranger, Terence (eds), The Invention of Tradition. Cambridge: Cambridge University Press.

1990. Nations and Nationalism since 1780. Programme, Myth, Reality. Cambridge: Cambridge University Press.

IBRĂILEANU, Garabet. 1970. Spiritul critic în cultura românească. Iaşi: Junimea.

IORGA, Nicolae. 1981. Eminescu. Iaşi: Junimea.

KEMP, Walter A. 1999. Nationalism and Communism in Eastern Europe and the Soviet Union: A Basic Contradiction? London: Macmillan.

KOLARZ, Walter. 1946. Myths and Realities in Eastern Europe. London: Lindsay Drummond.

LEMNY, Stefan. 2009. Les Cantemir: L'aventure europeenne d'une famille princiere au XVIIIe siècle. Paris: Editions Complexe.

LUNGU, Ioana. 2002. Romanian Constitutional Nationalism. Polish Sociological Review 4(140): 397-412.

MACMILLAN, Margaret. 2001. Peacemakers: The Paris Peace Conference of 1919 and Its Attempt to End War. London: John Murray.

MAIORESCU, Titu. 1966. Critice. Bucharest: Editura pentru literatură. 
MÂRZA, Radu. 2003. Timotei Cipariu şi probleme ale slavonismului românesc. Două scrisori către Franz Miklosich. Apulum 40(1): 343-360.

MIHAILESCU, Călin Andrei. 2006. Mihai Eminescu - The Foundational Truth of a Dual Lyre. In: Cornis-Pope, Marcel-Neubauer, John (eds), History of the Literary Cultures of East-Central Europe: Junctures and Disjunctures in the $19^{\text {th }}$ and $20^{\text {th }}$ Centuries. Vol. II. Amsterdam: John Benjamins.

MOLDOVEANU, Cerasela. 2020. 1940 - rapturile teritoriale. Soarta refugiaților din teritoriile anexate. Revista de istorie militară 2020/1-2: 45-55.

NIETZSCHE, Friedrich. 1997. Untimely Meditations. Cambridge: Cambridge University Press. (transl. by Hollingdale, R. J.).

OIŞTEANU, Andrei. 2009. Inventing the Jew: Antisemitic Stereotypes in Romanian and Other Central-East European Cultures. Lincoln: University of Nebraska Press.

PĂUNESCU, Adrian. 2010. Interviu cu poetul Adrian Păunescu de Gelu Diaconu. https://www.poezie.ro/index.php/article/13958829/Interviu_cu_poetul_ Adrian_P\%C4\%83unescu (last accessed: 3 December 2021).

PETRESCU, Dragoş. 2009. Community-Building and Identity Politics in GheorghiuDej's Romania, 1956-64. In: Tismaneanu, Vladimir (ed.), Stalinism Revisited: The Establishment of Communist Regimes in East-Central Europe. Budapest: Central European University Press.

SCHMITT, Oliver Jens. 2017. Corneliu Zelea Codreanu: Ascensiunea şi căderea „Căpitanului”. Bucharest: Humanitas. (transl. by Wilhelm Tauwinkl).

SHAPIRO, Henry. 1965. Red Cultural Influence Vanishing in Romania. The Wilmington News 16 July. https://news.google.com/newspapers?id=oIZkAAAA IBAJ\&pg=710,2798537 (last accessed: 3 December 2021).

SMITH, Anthony D. 1998. Nationalism and Modernism: A Critical Survey of Recent Theories of Nations and Nationalism. London-New York: Routledge.

TISMĂNEANU, Vladimir. 2007. Comisia prezidențială pentru analiza dictaturii comuniste din România: Raport final. Bucharest: Humanitas.

TREVOR-ROPER, Hugh. 1983. The Invention of Tradition: The Highland Tradition of Scotland. In: Hobsbawm, Eric-Ranger, Terence (eds), The Invention of Tradition. Cambridge: Cambridge University Press.

ȚENE, Ionuț. 2017. De ce l-au făcut „nebun” şi asasinat, cu ajutorul poliției secrete austriece, pe Mihai Eminescu. Napoca News, 15 June. https://www.napocanews. ro/2017/06/de-ce-l-au-facut-nebun-si-asasinat-cu-ajutorul-politiei-secreteaustriece-pe-mihai-eminescu-2.html (last accessed: 3 December 2021).

VERDERY, Katherine. 1991. National Ideology under Socialism: Identity and Cultural Politics in Ceauşescu's Romania. Berkely, Los Angeles-Oxford: University of California Press.

1993. Nationalism and National Sentiment in Post-Socialist Romania. Slavic Review 52(2): 179-203. 
WEBB, Adrian. 2008. The Routledge Companion to Central and Eastern Europe since 1919. Oxon-New York: Routledge.

ZAMFIRACHE, Cosmin Pătraşcu. 2019. De ce s-a ajuns la concluzia că Eminescu a fost asasinat. Comportamentul bizar al lui Titu Maiorescu în ziua internării poetului la ospiciu. Adevărul de Botoşani. https://adevarul.ro/locale/botosani/ de-s-a-ajuns-concluzia-eminescu-fost-asasinat-comportamentul-bizar-titumaiorescu-ziua-internarii-poetului-ospiciu-1_5d91de15892c0bb0c61b94b7/ index.html 1 Oct.2019 (last accessed: 3 December 2021).

ZWICK, Peter. 1983. National Communism. Boulder, CO: Westview Press. 